Dr RATOMIR MILIKIĆ, naučni saradnik

Institut za savremenu istoriju

Beograd, Trg Nikole Pašića 11

rasamilikic@gmail.com

UDK 94:355.134.2(497.1)"1941/1945"(093.2)

originalan naučni rad

314.745.3-054.7(=163.4/.6)"1941/1945"(093.2)

primljeno: 4. februar 2017.

prihvaćeno: 17. maj 2017.

\title{
DODELE ODLIKOVANJA KRALJEVINE JUGOSLAVIJE U EMIGRACIJI 1941-1945.
}

APSTRAKT: U članku se analizira do sada u nauci neobrađivana tema: dodele odlikovanja Kraljevine Jugoslavije tokom boravka kralja $i$ Vlade u emigraciji (Londonu i Kairu). Kako je dodela odlikovanja jedan od osnovnih prerogativa suverena, kao i Vlade, ona je u tim komplikovanim i nadasve teškim vremenima koje opserviramo, imala poseban simbolički značaj. Ne samo da su se dodele nastavile, već su izrađivana nova kovanja postojećih odlikovanja, a u fragmentovanoj i krajnje oskudnoj arhivskoj građi pronađen je i predlog tadašnjeg ministra vojnog, đenerala Dragoljuba Mihailovića za ustanovljenje novog odlikovanja, ali to nije realizovano. Rad se uglavnom zasniva na istraživanju u Arhivu Jugoslavije, gde su obrađeni fond Vlada u emigraciji i Lični fond Save Kosanovića.

KLJUČNE REČI: odlikovanja, Drugi svetski rat, Orden krst Majke Jugovića, Vlada u emigraciji, đeneral Dragoljub Mihailović, partizanski pokret, Jugoslavija

Odlikovanja (ordeni, medalje i spomenice) predstavljaju jedno od oličenja suverenosti države. Korene modernih odlikovanja valja tražiti u Rimskom carstvu, a oni posebno dobijaju značaj od vremena Francuske revolucije. Tako su prvo Burboni, a potom i Napoleon uveli praksu takvog nagrađivanja najistaknutijih i najodanijih ličnosti za vojne podvige ili usluge državi. Od 19. veka i druge države postepeno uvode tu praksu koja je podrazumevala da suveren po svom nahođenju odlikuje istaknute pojedince. U demokratskim društvima to se čini na predlog vlade. Svakako, dodela odlikovanja bila je neposredno vezana za pitanje suvereniteta. U tom periodu nastaju i moderni sistemi odlikovanja, čijem se razvojem bavi faleristika.

U srpskim zemljama prvo odlikovanje iskovano je 1841. godine u Crnoj Gori. Bila je to Medalja za hrabrost, koja je dodeljivana za herojske podvige u ratovima protiv Osmanskog carstva. Iako je Crna Gora dodeljivala odlikovanja i pre međunarodnog priznanja (1878), ona je i kroz njih zapravo pravila diskontinuitet sa Osman-

\footnotetext{
* Rad je deo projekta Konflikti i krize: saradnja i razvoj u Srbiji i regionu u 19. i 20. veku (47030) koji finansira Ministarstvo prosvete, nauke i tehnološkog razvoja Republike Srbije.
} 
skim carstvom kojem je formalno pripadala. Kneževina Srbija je obazrivije postupila i prvo odlikovanje (u formi spomenice) iskovano je 1865. godine povodom proslave pola veka od Drugog srpskog ustanka. Tada se povela rasprava o boji ordenske vrpce: iako je predlagano da bude u boji Osmanskog carstva (zelena), vrpca je na kraju bila crvena s belom i plavom ivicom. ${ }^{1}$ Spomen krst se dodeljivao isključivo preživelim učesnicima ustanka.

Prvo pravo odlikovanje ustanovio je kralj Milan po izbijanju rata sa Osmanskim carstvom (1876) i od tada se uspostavlja klasičan sistem odlikovanja Kneževine/Kraljevine Srbije koji se potom preneo u Kraljevinu SHS/Jugoslaviju. ${ }^{2}$ Ujedinjenjem 1918. godine, a posebno nakon proglašenja Jugoslavije, povećava se broj i proširuje međusobni odnos odlikovanja, koja su obilato dodeljivana za vojne zasluge $\mathrm{i}$ zasluge prema Kraljevini.

Kraljevska kancelarija ordena publikovala je u više navrata međusoban odnos odlikovanja koje je država dodeljivala i njihovih stepena. Tim dokumentima je propisano kako se odlikovanja nose u svečanim prilikama. Statutom svakog odlikovanja je precizno utvrđeno koja se odlikovanja mogu dodeljivati za učinjene usluge državi, kao i maksimalan broj dodela pojedinih redova. Svako odlikovanje je ustanovljeno posebnim zakonom koji je donela Narodna skupština.

Vlada u emigraciji je utvrdila i uporedan odnos odlikovanja Kraljevine, koji je poslednji put revidiran 1939. godine. Radi lakšeg razumevanja, dajemo spisak u celini.

01. Orden kneza Lazara

02. Karađorđeva zvezda sa mačevima I reda

03. Karađorđeva zvezda I reda

04. Karađorđeva zvezda sa mačevima II reda

05. Karađorđeva zvezda II reda

06. Beli orao sa mačevima I reda

07. Beli orao I reda

08. Karađorđeva zvezda sa mačevima III reda

09. Karađorđeva zvezda III reda

10. Beli orao sa mačevima II reda

11. Beli orao II reda

12. Jugoslovenska kruna I reda

13. Sveti Sava I reda

14. Karađorđeva zvezda sa mačevima IV reda

15. Karađorđeva zvezda IV reda

\footnotetext{
${ }^{1}$ Pavel Car and Tomislav Muhić, Serbian and Yugoslavian Orders and Decorations from 1859 to 1941 (Vienna: Verlag Militaria, 2009), 21.

${ }^{2}$ U Kraljevini Srbiji je za vreme vladavine Obrenovića postojalo pet odlikovanja (u civilnoj i vojnoj nomenklaturi), uz Orden Crvenog krsta, kao i brojne medalje i spomenice. Posle Majskog prevrata 1903. godine, Takovski krst zamenjuje Karađorđeva zvezda, Orden Miloša Velikog se ukida, ali se uvodi veći broj novih medalja (za hrabrost) i ratnih spomenica. U novu državu, Kraljevinu Srba, Hrvata i Slovenaca, Srbija kroz svoj suverenitet unosi i sistem odlikovanja, koji, po prirodi stvari, nosi isključivo obeležja Kraljevine Srbije. Proglašenjem Jugoslavije i zahvaljujući težnji kralja Aleksandra I da stvori jugoslovensku naciju, 1929. godine uvodi se jedino odlikovanje koje je imalo jedinstvene karakteristike zajedničke države - Orden jugoslovenske krune.
} 
16. Beli orao sa mačevima III reda

17. Beli orao III reda

18. Jugoslovenska kruna II reda

19. Sveti Sava II reda

20. Beli orao sa mačevima IV reda

21. Beli orao IV reda

22. Jugoslovenska kruna III reda

23. Sveti Sava III reda

24. Beli orao sa mačevima $\mathrm{V}$ reda

25. Zlatna i Srebrna vojnička Karađorđeva zvezda sa mačevima

26. Beli orao $\mathrm{V}$ reda

27. Jugoslovenska kruna IV reda

28. Sveti Sava IV reda

29. Jugoslovenska kruna V reda

30. Sveti Sava V reda

31. Zlatna i Srebrna medalja za hrabrost

32. Medalja Petra I

33. Albanska spomenica

34. Medalja za vojničke vrline

35. Zlatna i Srebrna medalja za revnosnu službu

36. Zlatna i Srebrna medalja za građanske zasluge

37. Krst milosrđa (ženski i muški)

38. Spomenice rata 1912. i 1913.

39. Spomenica rata 1914-18. godine

Posle završetka Velikog rata najveći broj odlikovanja dodeljen je za iskazanu hrabrost, sposobnost i primerenu službu tokom ratnih godina. ${ }^{3} \mathrm{Uz}$ to, prema podacima iz službenog glasila Kraljevine, primetan je značajan broj dodela (posebno odlikovanja u višim stupnjevima) istaknutim političarima i drugim javnim ličnostima iz „Novih krajeva“, sa teritorija Bosne, Slovenije i Hrvatske. Od prvih dana nove države, Dvor je nastojao da uspostavi izvesnu ravnotežu u dodelama odlikovanja ne bi li i na taj način ojačao osećaj pripadnosti novoj državi.

Budući da je vremenom nova država snažila, uobičajila se praksa da se dodeljuju odlikovanja za predan rad u državnoj službi. Tako su naučnici, diplomate, činovnici, upravnici državnih rudnika, kulturni radnici, bivali redovno odlikovani prigodnim odlikovanjima (najviše Ordenom Svetog Save).

Vojska je imala poseban status u državi, što se moglo videti i kroz odlikovanja. Pored četiri odlikovanja koja su dodeljivana za vojne zasluge, vojnicima je bio namenjen i niz medalja za hrabrost, revnosnu službu, vojne zasluge, ali i za pokazano znanje i umeće u pojedinim vojnim veštinama. ${ }^{4}$

${ }^{3}$ Sva odlikovanja Kraljevine su mogla da se dodele i za civilne i za vojne zasluge, dok su pojedina odlikovanja tzv. vojničkog reda (sa mačevima) bila namenjena isključivo vojnicima. Tako je čest primer da je neki oficir pored drugih zasluženih ordenja, medalja i spomenica, ponosno nosio i Orden Svetog Save ili Jugoslovenske krune, koji su važili za civilna odlikovanja.

${ }^{4}$ Još iz perioda Obrenovića postojale su medalje za dobrog strelca i dobrog nišandžiju topa, a u Kraljevini Jugoslaviji taj sistem vojničkih medalja dopunjuje se medaljama za posade topova od $37 \mathrm{~mm}$; 
Pored nacionalnih dodela koje su bile učestale u nastojanju da se proširi osećaj zajedništva u novoj državi, jedan od čestih vidova bilo je i dodeljivanje odličja stranim vojskovođama, oficirima i vojnicima koji su učestvovali u borbama na Solunskom frontu. Tako su brojni saveznički oficiri poneli visoka odlikovanja Kraljevine, a rađene su i posebne serije prigodnih spomenica za francuske vojnike. ${ }^{5}$ Svaku dodelu je pored uručenog odlikovanja pratio i personalizovan ukaz kralja.

Znatan broj odličja bio je namenjen za protokolarne svrhe. Kako je međunarodna saradnja dobijala zamah, tako je i broj dodela odlikovanja rastao. Pri tome nisu u pitanju samo posete na najvišem nivou, kada su vladari ili šefovi država razmenjivali odlikovanja, po pravilu u najvišem stupnju. Prilikom gotovo svih zvaničnih međudržavnih poseta dodeljivana su odlikovanja članovima delegacija i licima u njihovoj pratnji. Ta praksa je toliko uzela maha da su neretko odlikovani i horovi u poseti nekoj drugoj (prijateljskoj) zemlji. Tako je hor „Obilic“" prilikom posete Poljskoj 1937. odlikovan drugim po važnosti poljskim odlikovanjem Polonia Restituta. ${ }^{6}$ Praksa dodeljivanja odlikovanja gotovo svim pripadnicima diplomatskog kora po okončanju službe u zemlji prijema ili prilikom poseta visokih delegacija iz njihovih zemalja takođe je bila raširena.

Političke prilike u Kraljevini su se početkom 1941, kada se u Evropi uveliko zahuktavao Drugi svetski rat, dodatno pogoršale i iskomplikovale. Pristanak na pristupanje Trojnom paktu 25. marta 1941. doveo je do masovnog narodnog otpora i demonstracija u kojima su učestvovale najšire mase, simpatizeri i pripadnici većine političkih stranaka u zemlji. Vojni puč izvršen 27. marta, koji je jasno izrazio volju naroda, doneo je temeljne promene. Kralj Petar II je maloletan preuzeo vlast; Vladu su pod đeneralom Simovićem obrazovali predstavnici svih parlamentarnih stranaka (iz redova sva tri naroda), a stanovništvo je s velikim odobravanjem prihvatilo taj zaokret od politike Vlade Dragiše Cvetkovića i namesnika kneza Pavla Karađorđevića.

Pošto je Vlada imala neuporedivo važnije stvari da uradi na spoljnopolitičkom planu, kao i da izvrši opštu mobilizaciju, u periodu od 27. marta do 6. aprila 1941. nije poznat nijedan ukaz o dodeli nekog odlikovanja (za zasluge u martovskim dešavanjima majori-pučisti su odlikovani kasnije, od 1943. godine).

Kada je ujutro 6. aprila otpočeo krvavi Aprilski rat, pojedinačni herojski otpor Nemcima, ${ }^{7}$ slom vojske i povlačenje kralja, Vlade, dela vojske i predstavnika državnog aparata doveli su do potpuno novih okolnosti. Njihovo putešestvije avionom, pojedinim brodovima i podmornicom „Nebojša“ od Crne Gore preko Krfa, Atine,

dobrog mitraljesca i lakog mitraljesca, dobrog puškomitraljesca; dobre posade minobacača; da bi se spisak zatvorio u predvečerje rata (jul 1940) uvođenjem Medalje dobrom inženjercu.

${ }^{5}$ Reč je o posebnoj seriji Spomenice Velikog rata 1914-1918. urađenoj za francuske vojnike koji su se borili na Solunskom frontu.

${ }_{7}^{6}$ „Polonia Restituta“, Śpiewak, R. 18, (1937), nr 4.

${ }^{7}$ Istorijska je nepravda što je većina herojskih dela i ličnih žrtvovanja vojnika i oficira u Aprilskom ratu 1941. godine ostala neodlikovana tokom celog rata, kao i u komunističkoj Jugoslaviji. Jedini čin nedvosmislenog žrtvovanja koji su odlikovali i kralj i nova vlast u Jugoslaviji (ova druga, doduše, tek 1973) bila je pogibija poručnika Spasića i Mašere, koji su digli u vazduh razarač „Zagreb“ krajem Aprilskog rata 1941. Prvi spomenik branioci neba iznad Beograda iz 6. i pojedinci iz 4. i 5. lovačkog puka dobijaju tek devedesetih godina 20. veka, a 2002. tadašnji predsednik SRJ V. Koštunica posthumno ih odlikuje, kao i posadu monitora „Drava“ (koju je odlikovao i kralj u Londonu). 
Krita do Jerusalima i Aleksandrije nije ostavilo prostora da se razmišlja o odlikovanjima. ${ }^{8}$ Zbog okolnosti u kojima je povlačenje sprovedeno, nepoznata je sudbina jedina dva primerka dinastičkog Ordena kneza Lazara koja su ostala u Dvoru, sa mnogim ličnim predmetima dinastije Karađorđević.

Veći deo deponovanog zlata i neemitovanog novca iz trezora Narodne banke ostao je u zemlji, kao i znatan deo lične imovine i ušteđevine kralja. Iz raspoložive arhivske građe može se tačno rekonstruisati šta je poneto u emigraciju i u tim spiskovima nije se našlo nijedno odlikovanje (osim već dodeljenih, koje su pojedinci poneli sa sobom kao svoje vlasništvo).

Znatan broj stranih državljana odlikovan je odličjima Kraljevine Jugoslavije, kao i manji broj državljana Kraljevine koji se zatekao u emigraciji (podaci u priloženim tabelama). Kako valja odbaciti pretpostavku da su odlikovanja sakupljena iz raznih DKP Kraljevine po svetu (jer naprosto nije praksa da nedodeljena odličja stoje bilo gde mimo Kancelarije ordena), možemo s pravom pretpostaviti da su Dvor i Vlada u emigraciji učinili ono što su radile i druge zemlje (Francuska, Poljska, Čehoslovačka, Grčka i ostale zemlje čije su vlade boravile u Londonu). Odnosno, da su britanskim juvelirskim firmama poverili izradu novih odlikovanja. Isto je urađeno sa vazduhoplovnim znacima pilota Kraljevine, koji su napravljeni uz nove uniforme. Sledeći tu analogiju, s velikom sigurnošću možemo pretpostaviti da su i pojedina odlikovanja urađena u Velikoj Britaniji. ${ }^{9}$ Nesporne su dodele odlikovanja stranim državljanima, pošto se u arhivskoj građi pominje problem pakovanja za transport ordenâ belog orla sa mačevima namenjenih savezničkim pilotima. Iako na sednicama Vlade nije razmatrana politika dodele odlikovanja, već su samo pojedinačna ministarstva dostavljala predloge Dvoru, postoji posredan podatak o dodelama odlikovanja: tokom boravka Vlade u emigraciji, u dva navrata ministri su se dotakli finansijskog aspekta dodele odlikovanja, odnosno nabavki vrpci za lica odlikovana u savezničkim armijama. ${ }^{10}$

Jedino novo odlikovanje koje je uvedeno tokom Drugog svetskog rata u Kraljevini Jugoslaviji - Ratni krst 1941-1945, izrađivano je upravo u Londonu. To odlikovanje je imalo karakter ratne spomenice i dodeljivano je na znatno širim osnovama nego ostala odličja. Dodele odlikovanja kralja i Vlade u emigraciji mogu se podeliti u nekoliko kategorija:

${ }^{8}$ Uz više svedočenja, najdetaljnije i možda najplastičnije svedočenje o povlačenju dao je Miloš Trifunović, u: Коста Ст. Павловић, Ратни дневник 1941-1945 (Београд: Службени гласник, 2011), 206-207.

${ }^{9}$ Ionako težak posao tačnog utvrđivanja odakle potiču odlikovanja koje je kralj dodelio tokom Drugog svetskog rata, dodatno je iskomplikovan time što se $\mathrm{u}$ finansijskim dokumentima ne pominje taksativno izrada novih odlikovanja. Takođe, ne pominje se ni izrada novih letačkih znakova, već poimence samo izrada novih uniformi i opreme. Pretpostavljamo da je izrada odlikovanja vođena u okviru troškova Dvora ili pod stavkom drugih, nedefinisanih troškova tokom ratnih godina. U prilog tezi da su odlikovanja izrađivana u britanskim juvelirskim kompanijama, svedoči i podatak da je firma Spink proizvodila posle Drugog svetskog rata odlikovanja za kraljevsku kancelariju u egzilu. Detaljnije u: P. Car and T. Muhić, op. cit., 300.

${ }^{10} \mathrm{U}$ pitanju su odluke 109. sednice od 11. februara 1943. i 115. sednice od 6. maja 1943, obe održane u Londonu. Navedeno prema: Записници са седница Министарског савета Краљевине Југославије 1941-1945 (Београд: Службени гласник, 2004), 289, 317. 
- posthumna dodela odlikovanja državljanima Jugoslavije za borbu protiv neprijatelja u okupiranoj otadžbini (i u nekoliko slučajeva u sastavu Vazduhoplovstva SAD);

- dodela odlikovanja državljanima Jugoslavije za herojska dela u borbi protiv okupatora u okupiranoj otadžbini (uključujući i jedinu dodelu odličja jednom gradu Kragujevcu, povodom streljanja talaca u Šumaricama); žbine; ${ }^{11}$

- dodela odlikovanja jugoslovenskim državljanima za vojne zasluge van otad-

- dodela odlikovanja u diplomatske svrhe predstavnicima drugih vlada u emigraciji, kao i ličnostima iz SAD i Velike Britanije koje su pomagale Vladu u emigraciji;

- dodela odlikovanja predstavnicima savezničkih vojski.

Priložene tabele u kojima su navedene sve poznate dodele odlikovanja Jugoslavije tokom Drugog svetskog rata pokazuju da je najveći broj odličja namenjen borcima u okupiranoj otadžbini koji su pružali otpor neprijatelju, od kojih je većina položila i svoj život. Ne postoje podaci da je ijedna dodela tim kategorijama bila i upriličena, ali svakako se računalo da će do njih doći po okončanju rata i povratka kralja i Vlade u otadžbinu.

Sve dodele odlikovanja, osim za njega samoga, učinjene su na predlog ministra vojnog đenerala Mihailovića. On je preko britanske vojske prilično redovno održavao kontakte sa Vladom. Osim izveštaja sa terena, dostavljao je i predloge za odlikovanja i unapređenja vojnih lica pod njegovom komandom. ${ }^{12}$ Vlada je za napredovanje u službi do izvesnog ranga Mihailoviću ostavila nadležnost da o tome odlučuje. Tokom rata u Službenim novinama je objavljena procedura za dodelu odlikovanja. Lica koja su se našla u pisanim izveštajima ministra vojnog mogla su biti odlikovana ukazom kralja. ${ }^{13}$ Pri tom se strogo vodilo računa o ispunjenosti kriterijuma za dodelu pojedinih odlikovanja: oficiri su mogli dobiti samo određen rang odlikovanja, dok su za podoficire i vojnike bila predviđena druga odličja. ${ }^{14}$ Ravnopravnost je postojala samo pri dodeli medalja za hrabrost (Obilića) - nju su mogli dobiti svi činovi u vojsci. Za dodele u ostalim kategorijama nisu sačuvani drugi podaci osim kraljevih ukaza i informacija o odlikovanju koje su u većini slučajeva objavljivane u Službenim novinama. ${ }^{15}$

${ }^{11}$ Važno je naglasiti da tokom rata nije dodeljeno nijedno odlikovanje državljanima Kraljevine koji nisu bili vojna lica. Nijedan ministar u emigraciji ni druga istaknuta politička ličnost ili diplomata nisu odlikovani tokom Drugog svetskog rata jugoslovenskim odlikovanjima, osim Dragoljuba Mihailovića i to za vojne zasluge u zemlji. Odlikovani su i politički prvaci Jugoslovenske vojske u otadžbini, ali isključivo kao rezervni oficiri.

${ }^{12}$ Predloge za dodelu odlikovanja borcima JVuO davali su komandanti na terenu, često i preko mere, pa je Mihailović ustanovio komisiju za odlikovanja u Vrhovnoj komandi koja je procenjivala predloge. Detaljnije u: Бојан Димитријевић и Коста Николић, Бенерал Михаиловић - биографија (Београд: Институт за савремену историју, 2004), 384-385.

${ }^{13}$ To je francuski metod koji je primenjivan i u drugim vojskama. Različit rang pohvala (u zavisnosti od koga je pohvala dolazila) značio je i mogućnost da se dobije određeno odlikovanje.

${ }^{14}$ Oficiri su mogli da budu odlikovani Ordenom Karađorđeve zvezde (sa mačevima ili bez njih) i drugim odlikovanjima, dok je za podoficire i vojnike bio predviđen Vojnički orden Karađorđeve zvezde sa mačevima.

${ }^{15}$ Tokom emigracije kao jedino službeno glasilo izlazile su Službene novine. U periodu 19411945. štampana su ukupno 22 broja u Londonu i Kairu. Novine su nastavile tradiciju Službenih novina 
U Službenim novinama je već u prvom broju izašao ukaz o dodeli Ordena belog orla (V stepena) poručniku RAF-a dr Vilijamu Grifinu, ${ }^{16}$ od 1. juna 1941, donet u Jerusalimu. ${ }^{17}$ Reč je o prvoj dodeli odlikovanja u periodu haotične evakuacije iz Jugoslavije i boravka kralja i Vlade u Jerusalimu, jedinoj koja je publikovana u prvom broju Službenih novina.

U pogledu razumevanja kriterijuma za dodelu odlikovanja takođe je značajan podatak da je na sednici Ministarskog saveta održanoj 30. aprila 1941. u Jerusalimu predsednik Vlade đeneral Simović predložio da se odlikuju oficiri i mornari podmornice „Nebojša“, dve torpiljerke i posade osam hidroaviona ${ }^{18}$ koji su uspeli da dođu do Aleksandrije, ${ }^{19}$ ali to nije sprovedeno.

U trećem broju Službenih novina ${ }^{20}$ objavljen je kraljev ukaz o dodeli Ordena belog orla (V stepena) komandantu britanske podmornice „Trijumf“, od 1. novembra 1941, nesumnjivo zbog uspešne akcije ubacivanja prve grupe oficira za vezu sa Dragoljubom Mihailovićem, pod vođstvom Bila Hadsona. ${ }^{21}$ Oni su bili uspešno iskrcani nedaleko od Petrovca na moru. ${ }^{22}$

Prvi odlikovani pripadnici JVuO bili su majori Aleksandar Mišić i Ivo Fregl, ${ }^{23}$ koje su streljali Nemci. Obojica su odlikovana Ordenom Karađorđeve zvezde sa mačevima (IV stepena). To su ujedno bila prva lica koja su odlikovana na predlog novopostavljenog ministra vojske, mornarice i vazduhoplovstva, đenerala Mihailovića. U istom broju Službenih novina objavljen je ukaz o odlikovanju bivšeg vojnog izaslanika SAD u Jugoslaviji pukovnika Fortijea Ordenom belog orla sa mačevima (IV stepena).

U narednom periodu odlikovano je više istaknutih pripadnika JVuO. Tako su Ordenom Karađorđeve zvezde sa mačevima (IV stepena) odlikovani majori Dragiša Vasić i Jezdimir Dangić, kao i potpukovnik Dragoslav Pavlović. ${ }^{24}$ U istim Službenim novinama objavljen je ukaz o odlikovanju istim ordenom, ali posthumno, Milana Spasića i Sergeja Mašere, oficira razarača „Zagreb“ koji su digli u vazduh u Tivtu 17. aprila 1941. žrtvujući sopstvene živote. ${ }^{25}$ Odlikovan je i bivši vojni izaslanik Velike

Kraljevine i objavljivale su zvanične stavove Vlade, kao i kraljevska i ministarska rešenja i uredbe. Poslednji broj je izašao marta 1945. u Londonu.

${ }^{16}$ William P. Griffin, komandant baze RAF u severnoj Grčkoj gde je bila prva stanica tokom povlačenja kralja i Vlade.

${ }_{17}^{17}$ Službene novine, br. 1, London, 19. 8. 1941.

${ }^{18}$ Detaljnije o preletu hidroaviona u: Bojan B. Dimitrijević, Milan Micevski i Predrag Miladinović, Kraljevsko vazduhoplovstvo 1918-1944 (Beograd: Institut za savremenu istoriju, 2012), 461-462.

${ }^{19}$ Zapisnik 17. sednice Ministarskog saveta od 30. aprila 1941. održane u Jerusalimu. Navedeno prema: Записници са седница Министарског савета Краљевине Југославије 1941-1945, 16; Arhiv Jugoslavije (AJ), fond Save Kosanovića, 83-2.

${ }^{20}$ Službene novine, br. 3, London, decembar 1941.

${ }^{21}$ Duane Tyrell Hudson, poznatiji kao Bill Hudson (1910-1995), britanski oficir SOE i šef prve savezničke vojne misije u Jugoslaviji u Drugom svetskom ratu.

22 Detaljnije o ratnom putu britanske podmornice (koja je potonula 1942): http://uboat. net/allies/commanders/2712.html (pristupljeno 14. 12. 2016).

${ }^{23}$ „Kraljev ukaz od 14. januara 1942“, Službene novine, br. 4, 16. 1. 1942.

${ }^{24}$ Službene novine, br. 5, 31. 1. 1942.

${ }^{25}$ Tokom rata kralj je posthumno odlikovao nekoliko lica za herojska dela u Aprilskom ratu. Odlikovani su komandant monitora „Drava“ poručnik bojnog broda Aleksandar Berić, kao i poručnici Bruno Šegvić i Sulejman Šehović (Službene novine, br. 9, 6. 9. 1942). Takođe je odlikovan kapetan Dra- 
Britanije u Jugoslaviji, potpukovnik Čarls Klark i to Ordenom belog orla sa mačevima (IV stepena).

U Službenim novinama izašao je i veliki prilog o Dragoljubu Mihailoviću i drugim nosiocima Karađorđeve zvezde sa biografijama i podacima o njihovim junačkim delima. ${ }^{26}$ Tada su objavljeni ukazi o dodeli Ordena Karađorđeve zvezde sa mačevima (III stepena) ministru vojske đeneralu Mihailoviću, kao i ukazi o odlikovanju istim ordenom, ali IV stepena: kapetana Dragoslava Račića, a posthumno potpukovnika Veselina Misite, kapetana Tihomira Dejanovića i Bogdana Drljače, poručnika Mihajla Vujičića. Prva vojnička Zlatna medalja Karađorđeve zvezde sa mačevima uručena je posthumno naredniku Nikoli Markoviću.

Podaci o svim dodelama izvršenim tokom rata pokazuju da je posthumno za zasluge najviše dodeljivan Orden Karađorđeve zvezde sa mačevima (oficirskog i vojničkog reda), kao i medalje za hrabrost. Znatno ređe su dodeljivana druga odličja. Za vojne zasluge u zemlji prednjači Orden Karađorđeve zvezde sa mačevima, ali je primetna i značajna dodela Ordena belog orla sa mačevima, uz medalje za hrabrost.

Ukupno su registrovane 833 dodele različitih odlikovanja tokom Drugog svetskog rata, a njihovu preraspodelu pokazuje naredni dijagram:

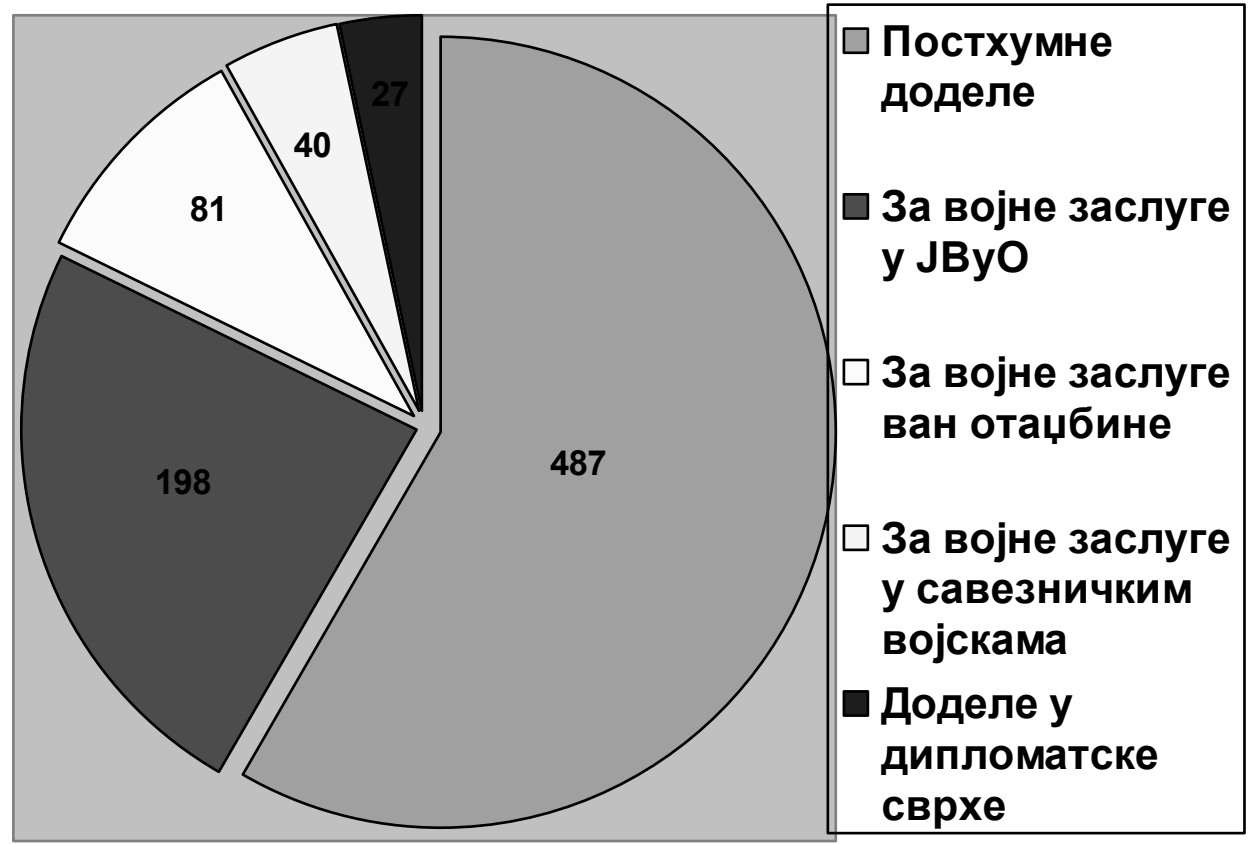

goljub Krgušić koji je herojski poginuo u okolini Kragujevca tokom Aprilskog rata (Službene novine, br. 10, 24. 11. 1942).

${ }^{26}$ Službene novine, br. 6, 30. 4. 1942. 
Posthumna dodela odlikovanja za borbu protiv neprijatelja u okupiranoj otadžbini

\begin{tabular}{|c|c|c|c|c|c|c|}
\hline & 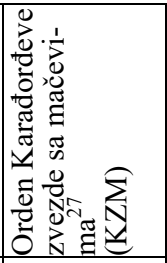 & 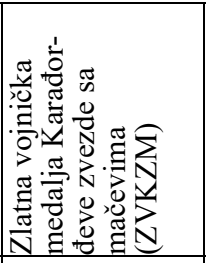 & 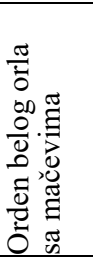 & 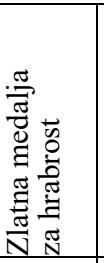 & 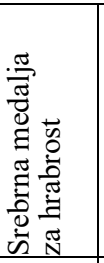 & 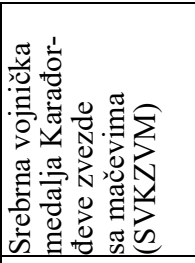 \\
\hline 1942. & 66 & 190 & & & & \\
\hline 1943. & $\begin{array}{r}9 \\
5^{28} \\
\end{array}$ & $\begin{array}{r}88 \\
4^{29} \\
\end{array}$ & & 6 & & \\
\hline 1944. & 3 & 18 & 5 & 33 & 50 & 10 \\
\hline Ukupno u zemlji & 78 & 296 & 5 & 39 & 50 & 10 \\
\hline \begin{tabular}{|l|} 
Ukupno u vojsci \\
van otadžbine
\end{tabular} & 5 & 4 & & & & \\
\hline
\end{tabular}

Dodela odlikovanja za vojne zasluge u borbi protiv neprijatelja u okupiranoj otadžbini

\begin{tabular}{|c|c|c|c|c|c|c|}
\hline & KZM & ZVKZM & SVKZVM & $\begin{array}{c}\text { Beli orao } \\
\text { sa mačevima }\end{array}$ & $\begin{array}{c}\text { Zlatna medalja } \\
\text { za hrabrost }\end{array}$ & $\begin{array}{c}\text { Srebrna medalja } \\
\text { za hrabrost }\end{array}$ \\
\hline 1942. & $14,1^{30}, 1^{31}$ & 9 & 5 & $6(\mathrm{IV}), 14(\mathrm{~V})$ & 50 & 49 \\
\hline 1943. & & 14 & 1 & 1 (IV) & 9 & 2 \\
\hline 1944. & 1 & 12 & & & $9^{32}$ & \\
\hline $\begin{array}{l}\text { Ukupno } \\
\text { u zemlji }\end{array}$ & $\begin{array}{r}17 \\
15(\mathrm{IV}) \\
1 \text { (III) } \\
1(\mathrm{I})\end{array}$ & 35 & 6 & $\begin{array}{r}21 \\
7(\mathrm{IV}) \\
14(\mathrm{~V})\end{array}$ & 68 & 51 \\
\hline
\end{tabular}

Dodela odlikovanja za vojne zasluge u borbi protiv neprijatelja van otadžbine

\begin{tabular}{|c|c|c|c|c|c|c|}
\hline & $\begin{array}{l}\text { Karađorđeva } \\
\text { zvezda } \\
(\mathrm{KZ})\end{array}$ & ZVKZM & Beli orao & $\begin{array}{l}\text { Beli orao } \\
\text { sa mačevima }\end{array}$ & $\begin{array}{l}\text { Zlatna meda- } \\
\text { lja za hrab- } \\
\text { rost }\end{array}$ & $\begin{array}{l}\text { Srebrna meda- } \\
\text { lja za hrabrost }\end{array}$ \\
\hline 1943. & 10 & 3 & & $\begin{array}{r}7^{33} \\
2\end{array}$ & $\begin{array}{r}9^{34} \\
3 \\
19\end{array}$ & $\begin{array}{r}4 \\
15\end{array}$ \\
\hline 1944. & 2 & 1 & 1 & 5 & & \\
\hline $\begin{array}{l}\text { Ukupno van } \\
\text { zemlje }\end{array}$ & 12 (IV) & 4 & $1(\mathrm{~V})$ & $14(\mathrm{~V})$ & 31 & 19 \\
\hline
\end{tabular}

${ }^{27}$ Svi dodeljeni ordeni su IV reda.

${ }_{28}^{28}$ Jugoslovenski piloti oboreni nad Nemačkom 19. decembra 1943.

${ }^{29}$ Isto.

${ }^{30}$ Dragoljubu Mihailoviću je tokom rata dodeljeno najviše priznanje - Orden Karađorđeve zvezde sa mačevima III reda. Službene novine, br. 6, 30. 4. 1942.

${ }^{31}$ Zbog stradanja u odmazdi koju je nemački okupator izvršio nad nedužnim civilima, kralj Petar II je odlikovao grad Kragujevac Ordenom Karađorđeve zvezde sa mačevima I reda. Službene novine, br. 10, 24. 11. 1942.

${ }_{32}$ Navedeni broj dodeljenih Zlatnih medalja za hrabrost, kao ni drugih odlikovanja posle juna 1944. nije konačan. Autor je imao priliku da vidi naredbu koja se nalazi u privatnom vlasništvu, a kojom đeneral Mihailović po odobrenju kralja obaveštava o dodeli Zlatne medalje za hrabrost žandarmerijskom naredniku Mitru Trivunčiću od 19. juna 1944. Taj podatak se nije našao u Službenim novinama.

${ }^{33}$ Za bekstvo iz zarobljeničkog logora. Službene novine, br. 11, 21. 3. 1943.

${ }^{34}$ Isto. 
Dodela odlikovanja u svrhe vojne diplomatije i za vojne zasluge u savezničkim vojskama

\begin{tabular}{|c|c|c|c|c|c|c|}
\hline & KZM & $\begin{array}{l}\text { Beli } \\
\text { orao }\end{array}$ & $\begin{array}{l}\text { Beli orao sa } \\
\text { mačevima }\end{array}$ & $\begin{array}{l}\text { Jugoslovenska } \\
\text { kruna }\end{array}$ & $\begin{array}{l}\text { Sveti } \\
\text { Sava }\end{array}$ & $\begin{array}{l}\text { Medalja } \\
\text { za vojnič- } \\
\text { ke vrline }\end{array}$ \\
\hline 1941. & & $2(\mathrm{~V})$ & & & & \\
\hline 1942. & & $\begin{array}{r}2(\mathrm{IV}) \\
1(\mathrm{~V})\end{array}$ & $\begin{array}{r}3(\mathrm{IV}) \\
5(\mathrm{~V})\end{array}$ & $\begin{array}{l}3 \text { (III) } \\
2 \text { (IV) }\end{array}$ & & \\
\hline 1943. & & & & & & \\
\hline 1944. & 2 (III) & $\begin{array}{r}2 \text { (II) } \\
3 \text { (III) } \\
2 \text { (V) } \\
\end{array}$ & $\begin{array}{r}1 \text { (II) } \\
1 \text { (III) } \\
1(\mathrm{~V}) \\
\end{array}$ & $\begin{array}{l}4 \text { (III) } \\
1 \text { (IV) }\end{array}$ & 2 (III) & 1 \\
\hline Ukupno & 2 & 12 & 11 & 10 & 2 & 1 \\
\hline
\end{tabular}

Dodela odlikovanja u diplomatske svrhe

\begin{tabular}{|c|c|c|}
\hline & Jugoslovenska kruna & Sveti Sava $^{35}$ \\
\hline \multicolumn{3}{|l|}{1941.} \\
\hline 1942. & $\begin{array}{l}1 \text { (I) Poljski poslanik Roman Dembic- } \\
\text { ki } \\
1 \text { (I) Poslanik SAD Artur Blis Lane }\end{array}$ & $\begin{array}{l}1 \text { (I) Vilijam Birks, predsednik kluba prijate- } \\
\text { lja Jugoslavije u Kanadi }\end{array}$ \\
\hline 1943. & $\begin{array}{l}1 \text { (II) } \\
\text { Paul Červinski, savetnik Poslanstva } \\
\text { Poljske }\end{array}$ & $\begin{array}{l}1 \text { (III) i } 1 \text { (IV) (protokol MIP SAD) } \\
2 \text { (III) } \\
\text { Maksvel Veil, industrijalac i publicista SAD } \\
\text { Francis Kosmerl, profesor univerziteta Čika- } \\
\text { go } \\
1 \text { (IV) Džejms Konoli, publicista SAD } \\
1 \text { (I) Hristo Diamantopulos, poslanik Grčke } \\
1 \text { (III) Čarls Id, novinar } \\
2 \text { (IV) } \\
\text { Spiros Skuras, predsednik filmske kompani- } \\
\text { je Foks } \\
\text { i Vilijam Gec, potpredsednik. } \\
6 \text { (V) ekipa filma } \\
1 \text { (V) g-đica Vera Holm }\end{array}$ \\
\hline 1944. & $\begin{array}{l}1 \text { (III) Žan Lugol, direktor novinskog } \\
\text { lista u Egiptu } \\
1 \text { (I) Ambasador SAD Antoni Dreksel } \\
\text { Bidl }\end{array}$ & $\begin{array}{l}1 \text { (IV) episkop Njujorka Vilijam Maning } \\
1 \text { (II) Edgar Galad, direktor novinskog lista } \\
\text { u Egiptu } \\
1 \text { (I) ser Tomas Kuk, poslanik Velike Brita- } \\
\text { nije }\end{array}$ \\
\hline Ukupno & 5 & 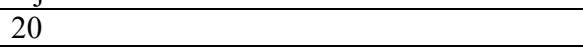 \\
\hline
\end{tabular}

Osim navedenih ukaza objavljenih u Službenim novinama, u Arhivu Jugosla$\mathrm{vije}^{36}$ se može pronaći još jedan broj potpisanih ukaza o dodeli odlikovanja kralja Petra II, pre svega ličnostima za diplomatske zasluge. ${ }^{37}$

${ }^{35}$ Osim navedenih, u AJ, fond Vlade u emigraciji 103-81, nalazi se i potpisani ukaz kralja Petra II o dodeli Ordena Svetog Save (I reda) Erveu Grandenu de l'Epervijeu, poslaniku Francuske u Jugoslaviji, od 17. avgusta 1943, na kome je navedeno da se ne publikuje.

${ }^{36}$ AJ-103-182.

${ }^{37}$ Takav primer je dodela Ordena Svetog Save (I reda) Morisu Dežanu, komesaru za spoljne poslove Slobodne Francuske u Londonu, od 22. septembra 1944, kao i zahtev britanskim vlastima za dodelu 
Posebno je vredna pomena grupna dodela Ordena Svetog Save čelnicima filmske kompanije Foks i ekipi igranog filma „Četnici“ u kome je 1943. godine prikazan (sa svim elementima vesterna) otpor Dragoljuba Mihailovića i Jugoslovenske vojske u otadžbini. Dodela stare zgrade Episkopalne crkve na Menhetnu Srpskoj pravoslavnoj crkvi i to što je SPC omogućeno da otkupi to zdanje po veoma povoljnoj ceni, kao i kontinuirano angažovanje u prikupljanju i slanju humanitarne pomoći postradalom narodu okupirane Jugoslavije, bili su razlog za dodelu istog odličja njujorškom episkopu te crkve Vilijamu Maningu (William Manning).

\section{Nova odlikovanja u Kraljevini Jugoslaviji}

Postoji jasan kontinuitet u ratnim planovima jugoslovenske države pred Drugi svetski rat, čak i organizacije rada Vlade u emigraciji, sa dešavanjima iz Prvog svetskog rata. Jedino što donekle odstupa od takve prakse jeste ustanovljavanje novih odlikovanja tokom emigracije.

To su jedno državno odlikovanje - Ratni krst 1941-1945, koje je dodeljivao kralj Petar II; Orden Svetog apostola Andrije Prvozvanog, koji je dodeljivalo istoimeno udruženje na čijem čelu se nalazila kraljica-majka Marija; neostvaren nacrt Ordena krst Majke Jugovića sa mačevima, odlikovanja zamišljeno na predlog đenerala Mihailovića koje zavređuje posebnu pažnju naučne javnosti.

Sporan je sam datum ustanovljenja Ratnog krsta 1941-1945. Izgleda da nacrt odlikovanja, kao i njegov naziv, potiču iz najranijeg posleratnog perioda. S druge strane, $u$ relevantnoj literaturi ${ }^{38}$ navodi se da je vreme ustanovljenja tog odlikovanja o kraljevom rođendanu septembra 1943. Ne želeći da bez uvida u neke do sada neotkrivene arhivske dokumente ${ }^{39}$ nagađamo da li je to odličje bilo ustanovljeno pre ili posle partizanskih odličja (koja su realizovana tek u drugoj polovini 1944, nakon prvih pošiljki odlikovanja iz Moskve na Vis), sa sigurnošću možemo utvrditi da je to bila ratna spomenica učesnika Drugog svetskog rata koji su se borili na strani legitimne Vlade u Londonu. Pravo na tu spomenicu imali su pripadnici JVuO, pripadnici vojske i drugih državnih organa u emigraciji koji su se aktivno borili za oslobođenje okupirane otadžbine, a kasnijim izmenama Statuta, i pripadnici savezničkih (zapadnih) vojski.

Trostepeni Orden Svetog apostola Andrije Prvozvanog, koji je dodeljivalo istoimeno društvo na čelu s kraljicom Marijom, ne spada u red državnih odlikovanja. Orden je uveden 9. oktobra 1943. i služio je kao nagrada Društva čiji su ciljevi bili definisani po uzoru na Jugoslovensko društvo Crvenog krsta: pomaganje i podizanje bolnica, organizovanje prve pomoći, pomoć ranjenoj deci i ratnoj siročadi, koordinacija i pomoć radu nejugoslovenskih organizacija. Društvo je osnovano u Londonu, a bilo je predviđeno da se po okončanju rata njegovo sedište premesti u Jugoslaviju. Po

dva ordena Belog orla britanskim oficirima, što je uobičajena diplomatska praksa. Navedeni slučajevi su se zbili u septembru i oktobru 1944.

38 Драгомир Ацовић, Слава и част: одликовања међу Србима, Срби међу одликовањима (Београд: Службени гласник, 2013), 157.

${ }_{39}$ Istraživačima ove teme rad je znatno otežan usled tendenciozno fragmentovane arhivske građe, tako da i mnogi dokumenti koji se pominju u sećanjima, posebno Koste St. Pavlovića, šefa kabineta predsednika nekoliko vlada u Londonu, ne mogu da se pronađu u dostupnoj arhivskoj građi. 
svom karakteru ovo odlikovanje pripada kategoriji poluzvaničnih odlikovanja, po analogiji sa Ordenom Crvenog krsta.

Najinteresantnije odlikovanje, koje do sada nije naučno obrađivano, jeste Orden krsta Majke Jugovića sa mačevima, koji je predložio ministar vojni đeneral Mihailović, verovatno krajem 1942. godine. U arhivskoj građi o tome postoje samo sporadični pomeni. ${ }^{40}$ Kako do sada nisu bili poznati podaci o tom nacrtu, ovom prilikom dajemo osnovne elemente pomenutog predloga. Orden krst Majke Jugovića zamišljen je kao odlikovanje za majke sinova ,izginulih isključivo u borbama sa neprijateljem za vreme rata u odbrani naroda i naše države Jugoslavije“. Budući da je u pitanju nacrt odlikovanja koje bi se dodeljivalo nakon okončanja rata, nije predloženo idejno rešenje ordena kao ni približan broj mogućih dodela.

Iz raspoloživih podataka možemo zaključiti da je reč o ordenu koji bi se dodeljivao verovatno svim majkama čiji su sinovi poginuli u ratu (što donekle snižava rang odlikovanja, jer se ne bi dodeljivalo prema ličnim zaslugama, odnosno imalo bi spomenički karakter, ali na užim osnovama: poput Albanske spomenice i potonje Partizanske spomenice). Tom tumačenju u prilog ide i pojašnjenje predloga za orden: „po smrti majke Orden neće moći nositi ni jedan drugi član porodice“. Kao što je to slučaj s nekim odlikovanjima Kraljevine i potonje Jugoslavije, nosioci tog odlikovanja imali bi izvesne materijalne povlastice: „Majke, pritežaoci ordena, od kojih će mnoge biti samohrane, imaće od njega one beneficije, izvesne koristi, koje imaju pritežaoci Ordena Karađorđeve zvezde i Belog orla, a koje su već poznate“.

U zaključku datog mišljenja ministar prosvete Miloš Trifunović preporučuje Vladi da usvoji predloženi Orden, kao i zakonski predlog o tome koji je izradio predsednik Vlade Slobodan Jovanović. ${ }^{41}$ Tim predlogom je utvrđeno da posle rata na predlog Ministarstva vojske otpočnu prve dodele ordena. „Podneti zakonski predlog i molba našeg druga ministra vojske, ima čisto moralni značaj; to je sada samo jedna uteha - moralno priznanje majkama čiji su sinovi izgubili svoje živote boreći se i braneći otadžbinu“", ističe ministar Trifunović.

Predlog za novo odlikovanje nikada nije sproveden u delo, verovatno zato što je odluku Vlade Slobodana Jovanovića pretekla junska kriza: 26. juna 1943. predsednik Vlade postao je Miloš Trifunović. Time se politička kriza nije okončala, pa je njegovu vladu 10. avgusta iste godine zamenila „činovnička“ Vlada Božidara Purića.

Namena Ordena sadržala je dosta originalno rešenje u Kraljevini, uz oslanjanje na pojedine uzore iz inostranstva samo u ponekim aspektima. U Kraljevini Srbiji i kasnije Jugoslaviji postojale su posthumne dodele odličja za herojska dela. U Francuskoj, Nemačkoj ali i SSSR-u i nekim drugim zemljama postojala su odlikovanja za majke, koja su dodeljivana za požrtvovanost u odgajanju dece i za njihovu brojnost. To bi, svakako, bilo jedinstveno rešenje da se ustanovi odlikovanje namenjeno isključivo majkama za dela njihovih sinova. I samo ime odlikovanja s razlogom je bilo čvrsto utemeljeno u nacionalnoj epici i kultu žrtve.

40 „Zapisnik Ministarskog saveta od 5. marta 1943“, u: Записниции седница Министарског савета Краљевине Југославије, 297; AJ-103-01, Izveštaj ministra Trifunovića o tom pitanju, 10. maj 1943.

\footnotetext{
${ }^{41}$ Tekst zakonskog predloga nije sačuvan u arhivi Vlade u emigraciji.
} 
Uz zvanična odlikovanja pojavljuju se i druga, ona za koja se pobrinuo ideološki protivnik: u zemlji iznurenoj kako okupacijom tako i teškim građanskim ratom, Titovi komunisti uvode ${ }^{42}$ i pre preuzimanja prerogativa vlasti na zasedanju AVNOJ-a u Jajcu 29. novembra 1943. nova odlikovanja za pripadnike svog pokreta. ${ }^{43}$ Prve dodele upriličene su tek kada su iz Moskve na Vis stigli prvi kontingenti tih odlikovanja, zajedno sa drugom vojnom pomoći u leto 1944. godine. Njihove dodele, karakter i nepostojanje kontinuiteta nisu predmet ovog članka, ali je izvesno da ta odličja nisu s formalne strane mogla imati državni karakter (već lokalni, partijski, odnosno partizanski), sve dok nije završena tranzicija vlasti.

Vlada u emigraciji je imala većinu prerogativa državnosti i vođenja kako spoljne tako i unutrašnje politike $u$ krajnje izmenjenim okolnostima. Vođenje spoljne politike u svetskom ratu sa privremenim sedištem Vlade koje se pomeralo od Jerusalima do Londona, a zatim i do Kaira, da bi opet bilo premešteno u London, bilo je intenzivno i vrlo široko postavljeno. Jedan od instrumenata te politike bile su dodele odlikovanja stranim državljanima u protokolarne i propagandne svrhe. Vredna pomena jeste činjenica da nijedan ministar u Vladi niti ma koji drugi civilni službenik nije odlikovan nijednim odlikovanjem tokom trajanja rata. To govori da je bilo predviđeno da se odlikovanja za nacionalni civilni doprinos dodeljuju tek po okončanju rata.

Dodele odlikovanja za vojne zasluge, u zemlji i u inostranstvu, kako domaćim licima tako i oficirima i podoficirima savezničkih vojski, bile su nastavak tradicije iz prethodnog rata. Predlog đenerala Mihailovića za Orden krsta Majke Jugovića sa mačevima predstavljao bi veoma inovativno i jedinstveno rešenje ne samo u posleratnoj Jugoslaviji već i šire. Posle promene državnog ustrojstva i prestanka postojanja Kraljevine Jugoslavije jedino preostalo odlikovanje - Ratni krst 1941-1945. i dalje je dodeljivano onim pripadnicima JVuO koji su izbegli iz otadžbine, kao i pripadnicima vojske i drugih državnih struktura koji se nisu vratili u novu, komunističku Jugoslaviju.

\section{IZVORI I LITERATURA}

- Arhiv Jugoslavije (AJ), fond 103, Vlada u emigraciji; fond 83, Sava Kosanović.

- Записници седница Министарског савета Краљевине Југославије. Београд: Службени гласник, 2004.

- Službene novine (1941-1945)

- Śpiewak (1937)

- Ацовић, Драгомир. Слава и част: одликоваға међу Србима, Срби међу одликовањима. Београд: Службени гласник, 2013.

${ }^{42}$ „Ukaz J. B. Tita od 15. avgusta 1943“, Bilten Vrhovnog štaba NOV i POJ, br. 29-31, jun, jul i avgust 1943.

${ }^{43}$ U pitanju su Orden narodnog heroja, Orden partizanske zvezde, Orden narodnog oslobođenja, Orden za hrabrost, Orden bratstva i jedinstva i Medalja za hrabrost. 
- Димитријевић Бојан, и Коста Николић. Бенерал Михаиловић - биографија. Београд: Институт за савремену историју, 2004.

- Dimitrijević Bojan B., Micevski Milan, i Predrag Miladinović. Kraljevsko vazduhoplovstvo 1918-1944. Beograd: Institut za savremenu istoriju, 2012.

- Павловић, Коста Ст. Ратни дневник 1941-1945. Београд: Службени гласник, 2011.

- Car Pavel, and Tomislav Muhić. Serbian and Yugoslavian Orders and Decorations from 1859 to 1941. Vienna: Verlag Militaria, 2009.

- http://uboat.net/allies/commanders/2712.html (pristupljeno 14. 12. 2016)

Ratomir Milikić

\section{DECORATIONS OF THE KINGDOM OF YUGOSLAVIA AWARDED BY GOVERNMENT-IN-EXILE FROM 1941 TO 1945}

\section{Summary}

The paper has explored the decorations of the Kingdom of Yugoslavia awarded by King Peter II and the Yugoslav royal government, living in exile in London and Cairo. It is the prerogative of a sovereign and his government to award decorations, and in an extremely complicated and difficult period we have observed, it had a profound symbolic meaning, too. Not only did they continue to award the decorations, but had the existing medals recoined, while in the fragmented archives contain even a proposal of then army minister, General Dragoljub Mihailović, that a new decoration be produced.

During the war, the number of awarded decorations dwindled, especially to the ministers and prominent figures in exile, and the Yugoslav Army in the Middle East, but those issued for protocolar purposes and to reward the bravery of soldiers in the occupied Yugoslavia did not subside in numbers.

A decision to decorate a foreign citizen is always a diplomatic move, either civilian or military. In the given period, high-ranking decorations were awarded to the foreigners who helped promote a state propaganda campaign. In a time of war, the army minister was entitled to use his own discretion to nominate for decorations the members of the Yugoslav Army in the Homeland for extreme bravery in combat, those killed in action in the first place.

When after 1944 political circumstances changed in the country, as well as globally, the Partisan movement awarded their own decorations, with the assistance of the Union of Soviet Socialist Republics, having made a clear break with the Kingdom's decorations. As the war drew to an end, the King in exile instituted the Royal War Cross to be awarded to the exiled members of the Yugoslav Army in the Homeland. 
KEYWORDS: Decorations, World War II, The Order of the Cross of Mother of the Jugović Brothers, Government-in-exile, General Dragoljub Mihailović, Partisan movement, Yugoslavia

\section{ВРУЧЕНИЕ НАГРАД КОРОЛЕВСТВА ЮГОСЛАВИЯ ВО ВРЕМЯ ПРЕБЫВАНИЯ ПРАВИТЕЛЬСТВА В ЭМИГРАЦИИ С 1941 ПО 1945 ГОД}

\section{Резюме}

В работе анализируется до сих пор не разработанная в науке тема: вручение наград Королевства Югославия в период пребывания короля и правительства в эмиграции (в Лондоне и Каире). С учетом того, что вручение наград - одна из основных прерогатив как суверена, так и правительства, награждение в то, прежде всего, сложное и тяжелое время, рассматриваемое в данной работе, имело особое символическое значение. Вручать награды не просто продолжили, но заново чеканили уже существующие награды, а в фрагментарных и крайне скудных архивных материалах найдено и предложение военного министра, генерала Драголюба Михайловича, ввести новую награду, проект которого, однако, не был реализован.

В период войны уменьшено число врученных наград, особенно самим членам правительства, уважаемым людям, оказавшимся беженцами, и Югославской армии на Ближнем Востоке, но не тех наград, которые вручали с целью соблюдения протокола и за героизм военных в оккупированной Югославии.

Вручения наград иностранным гражданам всегда рассматриваются как вид дипломатии, гражданской или военной. В данный период заметно участилось вручение высоких наград иностранным лицам, которые помогли в распространении государственной пропаганды. Военный министр в период войны был уполномочен, свободно оценивая, представлять к награде отдельных лиц из личного состава Югославской армии на родине (ЮАнР), которые особенно отличились в борьбе против оккупанта, и в первую очередь тех, кто в этой борьбе пожертвовал своей жизнью.

После изменения политической ситуации в мире и в стране, с 1944 года, партизанское движение при поддержке СССР вручает свои награды, полностью прерывая традицию наград Королевства. Перед завершением военных конфликтов король в эмиграции вводит также Военный крест, который вручается беженцам из состава ЮАнР.

КЛЮЧЕВЫЕ СЛОВА: Награды, Вторая мировая война, Орден «Крест Матери Юговичей», Правительство в эмиграции, Генерал Драголюб Михайлович, Партизанское движение, Югославия 